\title{
ПРОБЛЕМЫ И ПЕРСПЕКТИВЫ РЕАЛИЗАЦИИ ИНСТИТУЦИОНАЛЬНОГО ПОТЕНЦИАЛА ИНТЕГРАЦИИ РОССИИ И АРМЕНИИ
}

\author{
(c) 2021 Даниелян Артур Айказович \\ соискатель \\ кафедра экономики и управления предприятиями и производственными комплексами \\ Санкт-Петербургский государственный экономический университет, Россия, Санкт-Петербург \\ E-mail: Arthur_d@inbox.ru
}

В статье рассматриваются вопросы интеграции экономик Армении и России, в том числе в рамках ЕАЭС. Показаны основные направления экономического сотрудничества государств. Проанализированы возможные интеграционные действия отраслей экономики, в частности интеграции промышленных предприятий России и Армении, с целью реализации конкурентных преимуществ высокотехнологичных предприятий Республики Армения и выхода на внутренние рынки ЕАЭС.

Ключевые слова: интеграция, ЕАЭС, институциональный потенциал

Модернизация социально-экономических отношений в соответствии с меняющейся политико-экономической средой представляет собой отражение требования времени, независимо от того в какой форме и на какой стадии развития существует государство на современном этапе. При всех отличиях, характерных для каждой из стран постсоветского периода между ними есть немало общего, и во многом оно базируется на том, что приверженцы институционального направления современной экономической науки - называют «зависимость от предшествующего пути развития» стран. Соответственно, государственная политика, направленная на реализацию модернизации экономики и общества, должна учитывать как общее, свойственное многим странам постсоветского пространства, так и имманентную им специфику, сложившуюся за длительный период пребывания в тесных кооперационных связях с другими государствами - бывшими республиками CСCP.

Социально-экономическая направленность российских реформ была ориентирована на создание класса так называемых «эффективных собственников», сутью которого является максимизация собственной эффективности. Согласно данной логике, подобная политика может называться именно социально-экономической, поскольку формирование класса собственников происходит на основе уже сложившегося общества, что, по мнению реформаторов, должно было на основе определенной преемственности обеспечить экономическое процветание госу- дарства и решение социальных проблем.

Институциональная модернизация социально-экономических отношений, как известно, заключается в совершенствовании институциональной архитектуры социально-экономических систем, что требует установления соответствующих целевых ориентиров. Политика же, направленная на обновление интеграционных связей, должна развивать институциональную модернизацию социально-экономических отношений и основываться на иерархическом принципе.

Построение эффективной социальноэкономической политики невозможно без учета настоящего состояния экономики и анализа тенденций ее в ретроспективе. Проблема в том, что учет ретроспективы не означает переноса бывших тенденций на перспективу и не может быть предопределен с учетом только текущего социально-экономического состояния, т.е. главное в том, чтобы не попасть в плен ретроспективы и не перенести текущие тенденции на перспективу.

Вопрос об институциональной модернизации в Республике Армения в современных условиях и должен учитывать интеграцию ее экономики в рамках ЕАЭС, и, прежде всего с Россией. Если говорить о структуре транзакционного сектора Армении, то она, также, как и структура большинства стран, возникших на постсоветском пространстве, несет в себе именно ретроспективу. Так, для Армении, также, как и для России, характерна ориентация на банковскоориентированную модель финансирования 
предприятий, во всяком случае, в кратко- и среднесрочной перспективе.

Активизация, в том числе межгосударственных связей, привела к экономическому росту в Армении (рис. 1), что сказалось в определенной степени и на трансакционном секторе.

В январе 2015 года Армения стала участником Евразийского экономического союза (ЕАЭС). Сотрудничество Армении со странамиучастниками ЕАЭС началось еще в Таможенном союзе и Едином экономическом пространстве. В ноябре 2013 года был подписан «Меморандум об углублении взаимодействия между Евразийской экономической комиссией (ЕЭК) и Республикой Армения».

И только в октябре 2014 г. был подписан договор, по которому Армения должна была стать полноправным участником ЕАЭС 2 января 2015 года, что, в конечном итоге, привело к росту ВВП Армении. Как видно из рис. 1, темпы роста ВВП Армении увеличивались вплоть до 2020 года, когда в результате пандемии COVID-19 произошло падение его на 7,2\%. Взаимодействие республики со странами ЕАЭС может идти по нескольким направлениям, в первую очередь, в рамках внешней торговли.

Внешнеторговый оборот Армении в 2020 году составил 7,1 млрд. долл., в сравнении с аналогичным периодом предыдущего года этот показатель понизился на 13,2\% (в 2019 году - 8,2 млрд. долл.), а внешнеторговый оборот Армении со странами ЕАЭС составил 2,2 млрд. долл., снизившись на 2,6\% в сравнении с аналогичным периодом предыдущего года, в том чис- ле, с Россией $-2,1$ млрд. долл. (спад $-3,5 \%)$. За 2020 год экспорт из Армении составил 2,5 млрд. долл., снизившись на $3 \%$ в сравнении с аналогичным периодом предыдущего года. Экспорт из Республики Армения в страны - члены ЕАЭС составил 705,3 млн. долл., снизившись на 8,3\% [1].

Импорт в Армению в 2020 году составил 4,6 млрд. долл., сократившись по сравнению с предыдущим годом на $17,7 \%$, а импорт в Армению из стран ЕАЭС составил 1,5 млрд. долл., увеличившись на $0,2 \%$.

Локдаун и ограничения, введенные из-за пандемии COVID-19 в 2020 году, отрицательно повлияли на объемы взаимной торговли странчленов ЕАЭС, что, в основном, было связано с резким спадом объемов производства товаров и объемов потребления, последнее же, в результате мультипликативного эффекта привело к снижению объема транспортных перевозок, сферы услуг и ряда других отраслей экономики. Армения и Россия являются стратегическими партнерами и при этом Россия является лидером практически по всем макроэкономическим показателям стран-участниц СНГ и ЕАЭС.

Перед экономиками стран ЕАЭС, в том числе, России и Армении остро стоит проблема модернизации и инновационного развития на основе цифровой трансформации. Масштаб задач различен, однако необходимость в кардинальном обновлении как российской, так и армянской экономики, перевода промышленности на новые технологические уклады очевидна.

Анализируя стратегии экономического развития России и Армении до 2020 г., можно ска-

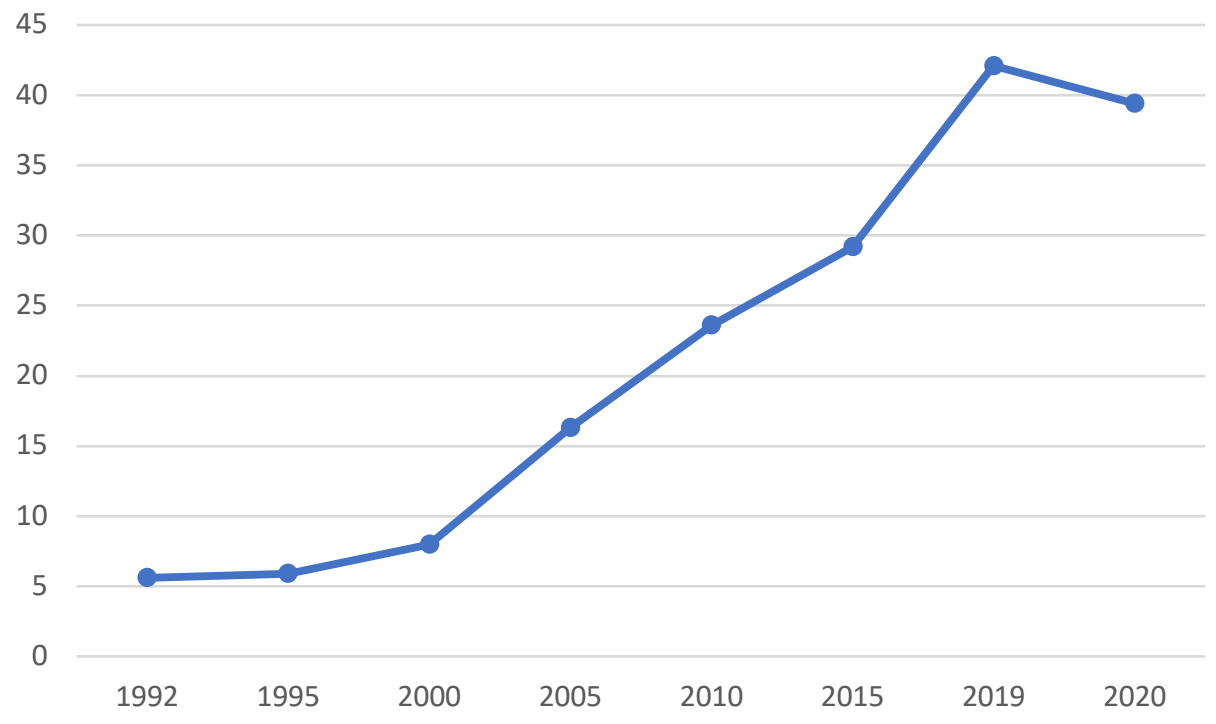

Puc. 1. Динамика ВВП Республики Армения, млрд. долл. 
зать, что приоритетными направлениями развития являются:

- Формирование предпосылок для развития общего экономического пространства.

- Развитие общих рынков отдельных видов продукции.

- Создание эффективных механизмов валютно-финансового сотрудничества.

Что касается перспективы дальнейшей интеграции Армении в ЕАЭС, то, как известно, Армения в наибольшей степени сотрудничает с Россией и Казахстаном. Анализ интеграционных тенденций в ЕАЭС показал, что рост торговоэкономических взаимоотношений с лидерами ЕАЭС (до последнего кризиса) дает возможность оценить интеграционный потенциал Армении.

Интеграция в какой-либо экономический союз предполагает соответствие страны определенным критериям, а именно: географическая близость, общая граница, равные экономические, политические социальные, культурные и иные показатели. Что касается политических, социальных и культурных норм, то Армения, как минимум, находится на уровне остальных стран-участниц ЕАЭС, хотя события, связанные с некоторой нестабильностью, конфликтом в Нагорном Карабахе, вместе с пандемией COVID-19, наложили свой отпечаток на роль и место Армении в ЕАЭС. Тем не менее, по остальным требованиям имеются определенные трудности:

- отсутствие общих границ с какой - либо из стран ЕАЭС усложняет углубление торговоэкономических отношений в рамках ЕАЭС;

- уровень экономического развития и сте- пени рыночной зрелости экономики пока не находится на уровне лидеров.

Несмотря на то, что проблемы являются фундаментальными, есть определенные механизмы их решения. Как показывает мировой опыт, важнейшим направлением развития экономических отношений, несомненно, является инвестиционное сотрудничество. Именно инвестиции способствуют созданию новых высокотехнологичных рабочих мест и позволяют упростить обмен в различных областях экономики, культуры и развития инфраструктуры. Динамика инвестиций в основной капитал стран ЕАЭС, в том числе, России и Армении в 2020 году была отрицательной, снижение составило по сравнению с предыдущим годом почти два процента, что явилось худшим показателем за период существования ЕАЭС за исключением 2015 года, когда сокращение инвестиций в основной капитал составляло 8,7\%. [2] Тем не менее, перспективы инвестирования России в экономику Армении представляются оптимистичными. Так, на 8-м Армяно-Российском межрегиональном форуме было заявлено, что Россия предполагает инвестировать в экономику Армении до 1 млрд. долл в ближайшее время. [3] Но проблема состоит в том, что Армении не хватает именно прямых иностранных инвестиций, которые и являются основой промышленного роста и роста конкурентоспособности государства.

На рис. 2 представлен график динамики прямых иностранных инвестиций за последние пять лет. [4]

Если не затрагивать последние два года, ко-

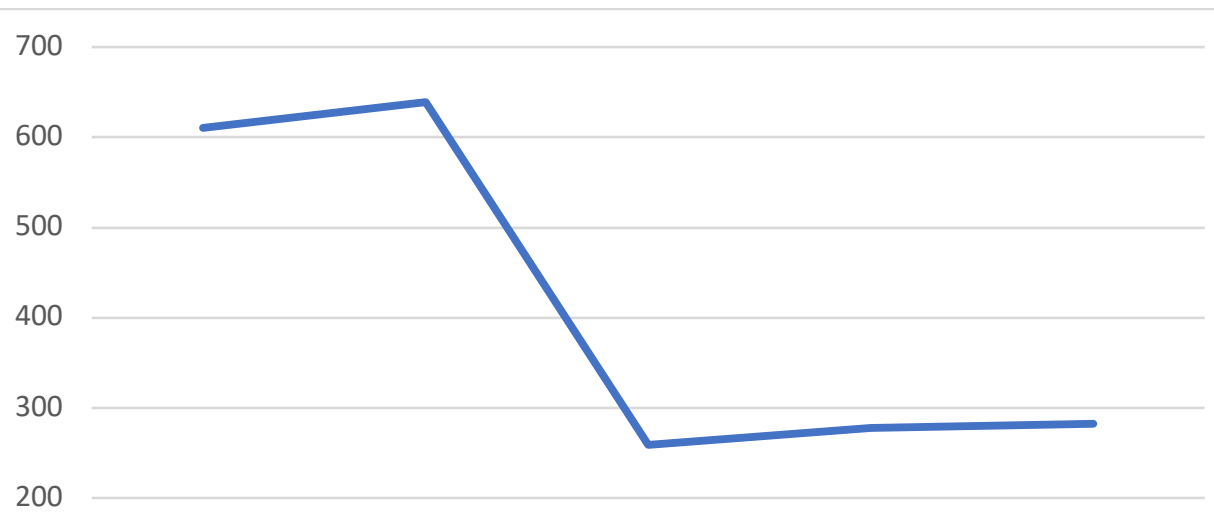

100

0 2016 2017 2018 2019 2020

Puc. 2. Динамика прямых иностранных инвестиций в экономику Армении, млн.долл. [5] 
торые не являются показательными, поскольку на инвестиционные показатели влияли все кризисные явления, то можно сказать, что за 2019 г. объем прямых инвестиций в Армению из России сократился до 33,2 млн. долл. США против 124,3 млн. долл. США за аналогичный период предыдущего года. Италия инвестировала в экономику Армении 27,1 млн.долл., Германия - 18,6 млн.долл.[6] Прямые иностранные инвестиции в основном затронули производство электроэнергии и газа; сферу недвижимости; деятельность воздушного транспорта; оптовую торговлю и т.д. [7] Нужно отметить, что политическая нестабильность достаточно сильно повлияла на инвестиционную привлекательность Армении (в том числе для стран, не входящих в ЕАЭС), и резкое снижение в 2018 году ПИИ, не восстановившееся вплоть до 2020 года. В этих условиях одним из наиболее значимых направлений интеграции промышленности Армении в международное экономическое пространство ЕАЭС является прямая интеграция предприятий Армении с российскими. Нужно отметить, что российский капитал достаточно интенсивно проникал в экономику Армении, однако в основном это осуществлялось на основе схемы «активы в обмен на долги». Прежде всего в 100-процентную российскую государственную собственность перешли предприятия, связанные с оборонно-промышленным комплексом, такие как «Марс» - завод электроники и робототехники (Ереван), предприятия, разрабатывавшие и выпускавшие средства автоматизированного управления и др. Это же касается ряда инфраструктурных предприятий, а также предприятий, связанных с распределением углеводородных энергоносителей. Перспективной отраслью экономики Армении, демонстрирующей, несмотря на некоторую внутреннюю нестабильность и внешние кризисные явления, 20-30\% ежегодного роста, и имеющей высокий потенциал технологического сотрудничества, является сфера информационных технологий. Нельзя сказать, что в этом отношении ничего не делается, так в настоящее время в Армении функционирует 2200 предприятий с российским капиталом, хотя в основном они сосредоточены в сферах с быстрым оборотом капитала.[8]

На наш взгляд, было эффективно использовать сотрудничество вплоть до прямой интеграции российских и армянских предприятий именно в тех сферах, в которых Армения традиционно имеет конкурентные преимущества, в том числе в виде квалифицированных кадров.

\section{Библиографический список}

1. Статистика внешнеторгового оборота Армении в 2020 году. https://news.myseldon.com/ru/news/ index/245139254

2. Об итогах и перспективах социально-экономического развития стран-членов Евразийского экономического союза и мерах, принятых государствами-членами в области макроэкономической политики. Годовой доклад за 2020 год. -Москва, 2021. https://eеc.eaeunion.org/upload/medialibrary/0ce/Annual-report-2020.pdf

3. Россия может в ближайшее время инвестировать $\$ 1$ млрд. в экономику Армении. https://tass.ru/ ekonomika/12699049

4. https://take-profit.org/statistics/foreign-direct-investment/armenia/

5. Статистический ежегодник Армении 2021 год. https://www.armstat.am/file/doc/99526913.pdf

6. Чистый приток ПИИ в Армению в 2019 году составил $\$ 254,5$ млн. https://eabr.org/press/news/chistyy-pritokpii-v-armeniyu-v-2019-godu-sostavil-254-5-mln/

7. Основные тенденции интеграционного развития Армении в 2019 году. Евразийский банк развития. Центр интеграционных исследований Дирекции по аналитической работе. 06.2020. https://eabr.org/upload/iblock/ bc9/EABR_RA_06_2020_RU.pdf

8. https://dommoskvy.am/russian-representative-offices/ 